The Roman Monster 


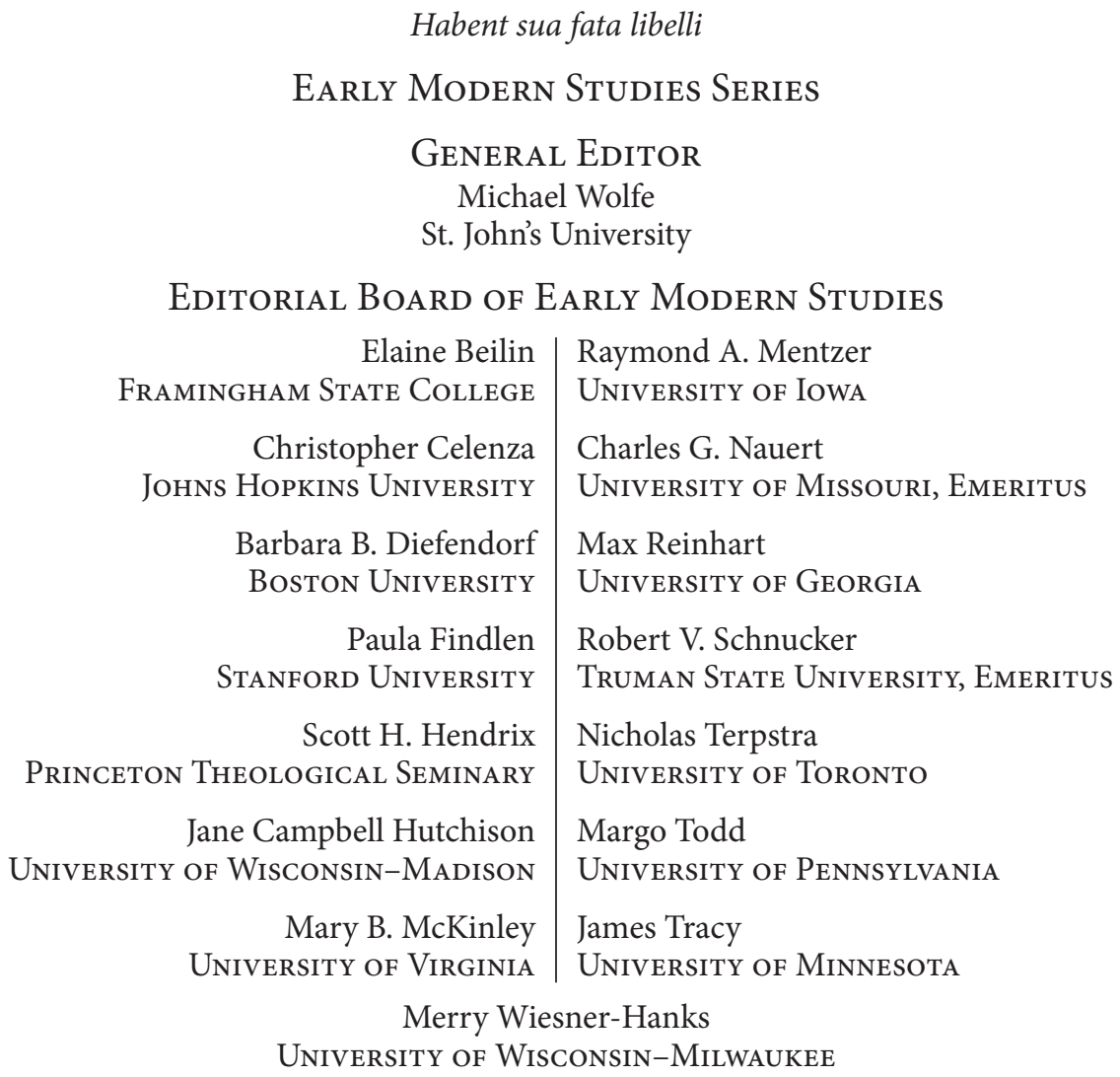




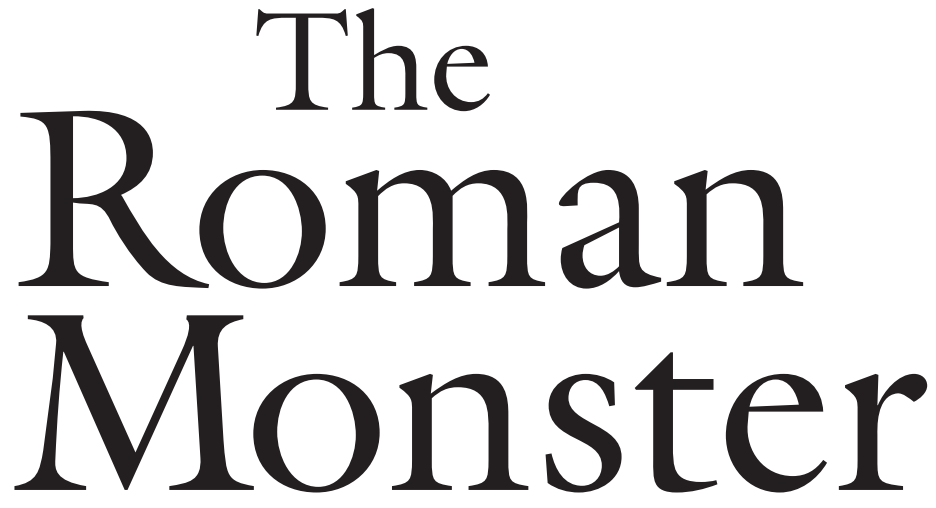

\section{An Icon of the Papal Antichrist in Reformation Polemics}

\section{LAWRENCE P. BUCK}

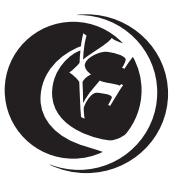

Early Modern Studies 13

Truman State University Press

Kirksville, Missouri 
Copyright (C) 2014 Truman State University Press, Kirksville, Missouri 63501

All rights reserved

tsup.truman.edu

Cover art: Roma caput mundi, reproduction of Roman Monster by Wenzel von Olmutz (1498); woodcut. Kupferstich-Kabinett, Staatliche Kunstsammlungen Dresden.

Cover design: Teresa Wheeler

Library of Congress Cataloging-in-Publication Data

Buck, Lawrence P. (Lawrence Paul), 1944-

The Roman monster : an icon of the Papal Antichrist in Reformation polemics / by Lawrence P. Buck.

pages $\mathrm{cm}$. - (Early modern studies ; 13)

Includes bibliographical references and index.

ISBN 978-1-61248-106-7 (paperback : alkaline paper) - ISBN 978-1-61248-107-4 (ebook) 1. Monsters-Religious aspects-Christianity-History. 2. Reformation. 3. Papacy-History. 4. Anti-Catholicism-History. 5. Antichrist in art. 6. Antichrist in literature. 7. End of the world-Biblical teaching. 8. Polemics-History. 9. Melanchthon, Philipp, 1497-1560 Criticism and interpretation. 10. Europe-Church history. I. Title.

BR307.B82 2014

$274^{\prime} .06-\mathrm{dc} 23$

2014008018

No part of this work may be reproduced or transmitted in any format by any means without written permission from the publisher.

The paper in this publication meets or exceeds the minimum requirements of the American National Standard for Information Sciences-Permanence of Paper for Printed Library Materials, ANSI Z39.48-1992. 
For Laura, David, and Judy. 
